
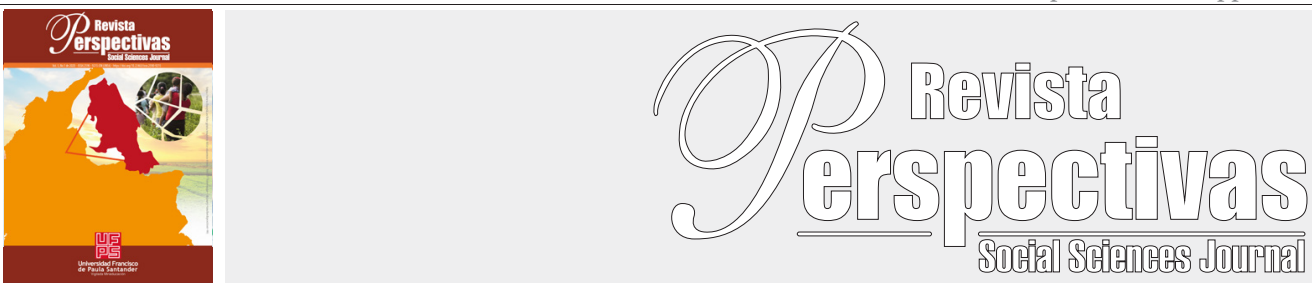

Artículo Original

https://doi.org/10.22463/25909215.2648

\title{
Promoting the rights of migrant children in the educational institutions on the colombian-venezuelan border.
}

\author{
La promocion de los derechos de la niñez migrante en las instituciones educativas de la frontera colombo- \\ venezolana.

\begin{abstract}
Liany Yetzira Hernández-Granados ${ }^{1}$, Javier Perozo-Hernández ${ }^{2}$, Yesli Geraldine Murillo-Amado ${ }^{3}$, Viviana Veronica Alarcon-Suarez ${ }^{4}$
${ }^{\prime}$ Magister en Derechos Humanos, Paz y Desarrollo Sostenible, lianyyetzirahg@ufps.edu.co,ORCID: 0000-0002-2503-1669,Universidad Francisco de Paula Santander,Cúcuta,Colombia ${ }^{2}$ Especialista en Derecho Contencioso Administrativo, ,ORCID: 0000-0002-4792-4468, Universidad Francisco de Paula Santander,Cúcuta, Colombia

${ }^{3}$ Docente Académico con énfasis en ciencias humanas, yesligeraldinemama@ufps.edu.co ,ORCID: 0000-0002-8501-0317,Universidad Francisco de Paula Santander,Cúcuta, Colombia ${ }^{4}$ Normalista Superior, vivianaveronicaasua@ufps.edu.co, ORCID: 0000-0002-7223-8347, Universidad Francisco de Paula Santander,Cúcuta,Colombia
\end{abstract}

Cómo citar: L.Y Hernández-Granados, J. Perozo-Hernández, Y.G Murillo-Amado, V.V Alarcon-Suarez "Promoting the rights of migrant children in the educational institutions on the colombian-venezuelan border.". Revistas Perspectivas, 5, No1, 104-113, 2020.

Recibido: August 02, 2019; Aprobado: November 15, 2019.

\begin{tabular}{ll}
\hline & RESUMEN \\
\hline Palabras clave: & $\begin{array}{l}\text { El presente artículo surge ante el panorama de la crisis política, económica y social, que ha sufrido el vecino país } \\
\text { de Venezuela durante los últimos años, lo que ha ocasionado que un gran número de la población venezolana } \\
\text { Educación, }\end{array}$ \\
decidiera migrar a diferentes países en busca de mejores condiciones de vida. Entre ellos se encuentran \\
niños y niñas, que ante la necesidad de continuar su proceso educativo han iniciado sus estudios en diversos \\
Niñez Migrante, \\
colegios públicos de la ciudad de San José de Cúcuta. Este nuevo fenómeno, ha provocado un cambio en los \\
Xenofobia, \\
ambientes escolares, con diferentes consecuencias, entre ellas, el riesgo, siempre creciente de problemáticas \\
de discriminación y xenofobia, donde niños y niñas venezolanos pueden verse expuestos a sufrir de vejámenes \\
por su condición socio-económica y su edad. A partir de esta situación desde el Semillero de Investigación en \\
Derechos Humanos -SEMDHUM-, adscrito al programa de Derecho de la Universidad Francisco de Paula \\
Santander, se planteó un proyecto de extensión que desarrollara una cultura de paz y convivencia, partiendo de \\
la indagación del marco normativo internacional y nacional respecto al derecho a la educación y la igualdad \\
de la niñez migrante, igualmente se generaron espacios lúdicos pedagógicos en las instituciones educativas \\
publicas de básica primaria de la ciudad de San José de Cúcuta, con el fin de concientizar y capacitar sobre los \\
derechos de la niñez migrante en la escuela y así apropiar a los niños y niñas en derechos humanos, igualdad \\
y no discriminación. Para realizar este proyecto se aplicó la metodología cualitativa y el método lúdico \\
pedagógico, por medio de actividades y juegos, donde el niño aprende y demuestra sus diferentes perspectivas \\
y conocimientos, mejorando el entorno estudiantil y cultural.
\end{tabular}

\section{ABSTRACT}

\section{Keywords:}

Education, Human Rights, Migrant Children, Xenophobia, Culture of Peace.
This article arises before the panorama of the political, economic and social crisis that the neighboring country of Venezuela has suffered in recent years, which has caused a large number of the Venezuelan population to migrate to different countries in search of better life conditions. Among them are boys and girls, who, faced with the need to continue their educational process, have begun their studies in various public schools in the city of San José de Cúcuta. This new phenomenon has caused a change in school environments, with different consequences, including the ever-increasing risk of problems of discrimination and xenophobia, where Venezuelan boys and girls may be exposed to abuse due to their socio-economic condition and their age. Based on this situation, the Human Rights Research Seedbed -SEMDHUM-, attached to the Law program of the Francisco de Paula Santander University, proposed an extension project that developed a culture of peace and coexistence, based on the investigation of the International and national normative framework regarding the right to education and equality of migrant children, educational pedagogical spaces were also generated in public primary educational institutions in the city of San José de Cúcuta, in order to raise awareness and train on the rights of migrant children in school and thus appropriate children in human rights, equality and nondiscrimination. To carry out this project, the qualitative methodology and the pedagogical play method were applied, through activities and games, where the child learns and demonstrates their different perspectives and knowledge, improving the student and cultural environment.

*Corresponding author.

E-mail address: yesligeraldinemama@ufps.edu.co (Liany Yetzira Hernández-Granados) 


\section{Introduction}

As members of the academy and part of the seedbed for research on human rights (SEMDHUM), we are carrying out this project focused on children, with the aim of influencing the problems of the region where we develop, mainly in migrant children who are studying in the educational institutions of the city of San José de Cúcuta, coming from the neighbouring country, Venezuela.

The wave of Venezuelan migrants to Colombia in recent years is a notorious fact, whether for political, economic or social reasons, who, faced with difficult living conditions, have found no other choice but to leave their country of origin in search of better opportunities for themselves and their families, thus finding children within that population.

Colombia, as a receiving country, and with the collaboration of the international community, has adopted various measures to improve the situation of Venezuelan migrants, including access to education for migrant children.

However, there are difficulties in including children, due to factors such as cultural differences, age discrimination and educational level; that is why training days were held on equality and nondiscrimination, human rights and a culture of peace, to promote the eradication of xenophobia in the educational institutions with the largest influx of migrant children in the city of San José de Cúcuta.

\section{The right to equality and education of migrant children}

The Universal Declaration of Human Rights does not refer to any specific group of people, but to human beings in general, and children adhere to the rights set out in its articles, such as equality and non-discrimination, establishing in particular that children have the right to special care and assistance.
The Convention on the Rights of the Child of 1989 constitutes a step forward in the recognition of children as social, economic, political, civil and cultural agents, giving children social protection and relevance in its content, stating that due to their lack of physical and mental maturity they need special protection and care.

The scope of protection does not include any distinction or discrimination with regard to the relationship of children with a State, that is, its inclusive language encompasses migrant children, without differentiating between nationals and foreigners, or those in a regular or irregular situation. In this line, article 2 of the Convention determines that each child subject to State jurisdiction will be respected in the rights set forth therein: ... without distinction of any kind, irrespective of race, colour, sex, language, religion, political or other opinion, national, ethnic or social origin, property, disability, birth or other status.

In turn, States parties are required to take all appropriate measures to ensure that the child is protected against all forms of discrimination or punishment. Article 28 recognizes the right to education, and its promotion on an equal basis.

Inclusive education is also promoted by recognizing the characteristics and particularities of diverse population groups, including migrant children and children in border situations, by stipulating in article 29 that education for children should be directed to respect for parents, for their own cultural identity, language and values, for the national values of the country in which they live, the country from which they originate and for civilizations different from their own.

The impact of migration on the rights of children and adolescents can be seen in all kinds of effects, with the consequent violation of their human rights, the interruption of their life projects and the conditions for a dignified life. 
This problem is aggravated when migration is not regular, which leads to obstacles in the recognition of their legal personality, in terms of documentation, nationality, name, access to health and education, among others, making them more prone and vulnerable to crimes such as trafficking in women, child labour, recruitment of minors or illegal adoptions.

Similarly, the Convention on the Protection of the Rights of All Migrant Workers and Members of Their Families, in its third part, grants a wide range of rights to all migrant workers and members of their families, regardless of their status, as long as they are migrant workers.

The effects of such a convention are dealt with in article 4, which specifies that the term "family members" refers to persons married to migrant workers and their dependent children, i.e. children and adolescents, and other dependants recognized as family members by applicable law or by applicable bilateral or multilateral agreements between the States concerned.

Article 30 stipulates that all children of migrant workers shall enjoy the fundamental right of access to education on the basis of equality of treatment with nationals of the State concerned. Access to pre-school institutions or public schools shall not be denied or restricted on the grounds of the irregular status in respect of the stay or employment of either parent, and the integration of children of migrant workers into the school system and in the local language, as well as access to social and health services, shall be facilitated.

The IACHR (2005) has stated that the object and purpose of the Convention is the protection of the rights of all human beings in the Americas, regardless of their nationality.

We can conclude that the principle of nondiscrimination is a guiding principle for States and that they are obliged to abolish any practice that entails discrimination; children cannot be deprived of their rights because of their migratory status; on the contrary, public policies must be designed to allow real inclusion in the participation of society, providing them with quality education.

The Political Constitution of 1991, professes the equality of rights between nationals and foreigners, expressly points out the fundamental rights of children and the principle of the best interest of the child. Law No. 1098 of 2006, known as the Children's and Adolescents' Code, provides for the comprehensive protection of children and adolescents as subjects of rights, their guarantee and fulfilment, as well as prevention of threats or violations, promotion and development of the best interests of the child, prevalence of their rights, solidarity, equity and complementarity. All this is embodied in a set of policies, plans, programmes and actions at the national, departmental and municipal levels.

After this look at the international and national level, it is clear that the integration of migrant children and adolescents not only implies the exercise of their rights to education or health, but also integration into the socio-cultural forms of being a child, here and now (Feixa, 2006).

Sometimes, in order to be accepted in their peer groups, they will be forced to imitate the cultural styles and language of indigenous children, an adaptation that can involve contradictions and generational conflicts with their families (Alegre, 2007).

For this reason, schools play a fundamental role in the integration process experienced by migrant children, as part of their function is to form subjects of rights, who are recognized as such and who promote democratic scenarios of participation and representation, with a clear sense of social responsibility and the search for general well- 
being, since they are the space where they develop and have the possibility of creating links. For this reason, education, in addition to being a right, is also an obligation, since it constitutes a privileged mechanism of social and cultural reproduction (Suárez Orozco, 2008).

\section{He migration of venezuelan children in the bor- der city of san josé de cúcuta}

Migration has been present throughout the history of humanity, for the simple reason of supplying the need to seek better opportunities in other territories, as the manifestation of the human being's will to overcome adversity and have a better life (United Nations General Assembly, 2006).

Migration refers to the movement of people who intend to change their residence from one place of origin to another destination, crossing some geographical boundary, which is generally a political-administrative divide. Currently, in the globalized world this phenomenon occurs due to social, political, economic problems, etc., for this reason, some sociologists consider that the $21 \mathrm{st}$ century has been characterized as the century of migration (Ruiz García, 2002).

Colombia, specifically on the ColombianVenezuelan border, has been the recipient of a large wave of migrants from neighbouring Venezuela. According to data from the International Organization for Migration, by 2018 more than 2.3 million people have left Venezuela during the previous two years. For Migration Colombia, as of September 30, 2018, there were about 1,032,016 regular Venezuelan citizens (entered through authorized points and have the established documentation) and irregulars (entered the territory through unauthorized passages or exceeded the time allowed) who intended to remain in the national territory.

Among the different causes that may lead to the emergence of migration are physical and human causes. In the physical ones, natural disasters are considered and in the human ones, politics, religion and economy are the main ones. Without leaving aside the motivations due to war and social conflicts (Echeverry, 2012).

The most notorious trigger on the Venezuelan border is economic, as well as social and political factors (Sandell, Sorroza and Olivié, 2017).

That is why migration waves originate from countries that are economically and politically unstable -that is why comparatively more unfavourable- towards others, with more favourable possibilities. (From flowers, 2017). This is how the waves of migration have been seen for several years at the global level. In 2014, the international price of oil plummeted, and economic policies gave rise to a political and social crisis, with repercussions for Venezuela, among other political and social factors, of a serious shortage of foodstuffs, medicines, etc.

Kruger Sarmiento (2017) also discusses three aspects related to migration between Colombia and Venezuela: the first is its history and geographical proximity; the second is the growth of migratory flows in recent years, where other countries have reached $11 \%$ and Venezuela $15 \%$; the third is the current dynamic, where we observe pendulum migration, that is, migration that moves regularly between the two countries in the border area.

In spite of the constant pointed out in time, although in small dimensions, currently the receiving areas are collapsing, due to the pressure that is being exerted on the institutions, the systems of services provision, the labor market and the social dynamics of the receiving areas, in order to give an answer to the needs of the Colombian citizens and the Venezuelan migrants.

The World Bank (2018), in classifying the characteristics of migration from Venezuela to Colombia, shows the measures that have been adopted by the receiving country. Thus, in 2017, 
new provisions were included to improve the management of the migrant population and access to basic services. During this year the TMF (Border Mobilization Card) was created, this card gives access to the national territory for seven days and only for the border area. Regulars were also given a migratory status with the intention of staying, so that they could work and access health, education and financial services; the PEP (Special Permit to Stay) was created for this purpose. In terms of services, emergency health care, education for migrant children and early childhood care were provided.

En materia de educación, se extendió el acceso a los migrantes, por esto pueden contar con el Plan de Alimentación Escolar (PAE) y el servicio de transporte escolar; también se flexibilizaron los requerimientos para acceder, permanecer y finalizar los ciclos educativos, facilitando la convalidación de estudios, acudiendo además a la tabla de equivalencia de los dos países. Pero esto ha originado ciertos inconvenientes en las instituciones ya que al realizar una prueba para revisar en qué nivel están los estudiantes, los conocimientos que estos tienen no son los respectivos al nivel educativo, así que son ubicados en un nivel inferior o superior, respectivamente.

A septiembre del 2018, según cifras entregadas por el Ministerio de Relaciones Exteriores, habían aproximadamente 1'235.593 personas con intención depermanencia en territorio colombiano provenientes de Venezuela, incluyendo a retornados y migrantes regulares e irregulares. Con el fin de dar respuesta a la problemática se han adoptado diferentes medidas como la construcción de albergues y jornadas de salud. (Gerencia de Frontera, 2018).

ElCONPES 3950 del año 2018, diseñó la política pública o estrategia para la atención de la migración desde Venezuela, resaltando que en materia de educación el Ministerio de Educación Nacional publicó las circulares nro. 45 del 16 de septiembre de 2015, nro. 07 del 2 de febrero de 2016, nro. 01 del
27 de abril de 2017, y nro. 16 del 10 de abril de 2018, estas dos últimas conjuntas con Migración Colombia, para orientar a las entidades territoriales certificadas (ETC) sobre los mecanismos para atender a los estudiantes migrantes procedentes de Venezuela, en los procesos de matrícula, convalidación de estudios y validación de grados de preescolar, básica y media independientemente de su estatus migratorio, se adoptaron programas de alimentación y transporte escolar, así como un corredor humanitario para que niños y niñas puedan continuar su proceso educativo.

En el 2018 se dio una ruta de atención para migrantes venezolanos, sobre el acceso a la educación para estudiantes migrantes: Se hizo viable que niños, niñas y adolescentes (NNA) procedentes de Venezuela pudieran acceder a la escuela, solamente se dio como requisito que los padres de familia del estudiante acudieran a la institución educativa o la Secretaria de Educación, y solicitaran un cupo, ya sea en educación preescolar, básica y media. Luego, el rector o rectora contará con un plazo máximo de 30 días hábiles para incluir al solicitante en el Sistema de Información para el Reporte de Extranjeros. (Unidad Nacional para la Gestión del Riesgo de Desastres Colombia, 2018)

\section{Recreational and educational activities in the schools of san josé de cúcuta}

In accordance with the above context, and from the social function of the Universidad Francisco de Paula Santander, through the extension, a project was proposed that would contribute to society in a critical and creative way, sharing the results and achievements of the academy, in a dialogue and intervention of the needs of local communities and families. Research, together with teaching and extension, are part of the fundamental pillars of the University. It is impossible to conceive of a higher education institution without generating research processes that will stimulate the construction of knowledge and social change as a result of these processes (AA Gamboa-Suárez) 
Resolution No. 121 of May 24, 2011 of the Academic Council regulates the process of research training through the research seedbeds. The responsibilities of the Human Rights Research Seedbed -SEMDHUM-, assigned to the Law program, include social responsibility with the environment in which it operates.

As the school is an optimal space to live the rights and development environment of children and adolescents, it ends up becoming a bridge of inclusion between receiving communities and migrants. Therefore, when identifying the problem of child migration in the educational entities of the city of San José de Cúcuta, methodological strategies and collaborative work on the acceptance of differences, respect, equality and non-discrimination in childhood were considered.

The playfulness used as a pedagogical strategy to strengthen school coexistence opens a learning path towards the joy of knowledge and the capacity of the human being to adopt a playful attitude (Huizinga, 1987), which involves curiosity, experimentation, dialogue and reflection. It is through the experience of different experiences that it is possible to arrive at a playful pedagogy which is presented as a didactic proposal of enjoyment and challenge (Posso, Sepulveda, Navarro and Laguna, 2015), This is why play is presented as a fundamental basis for building confidence and increasing motivation in learning (Ferrari, 1994).

According to Duarte (2003) the incorporation of play in educational environments is pertinent, since it allows the development of processes for the construction of identity and cognitive belonging, highlighting the relationship between play, thought and language, allowing an enriching scenario for the child to get to know his/her environment and develop mental processes.
That is why we applied the pedagogical ludic methodology to reach the children, moving away from traditional classes, presenting an interactive content, where each activity had a meaning, allowing to build a knowledge from their pre knowledge about human rights and the situation that is being lived in the city because it is a border, as well as the acceptance without any kind of discrimination of their peers from the neighboring country.

We propose as objectives the promotion of human rights, especially equality, the establishment of spaces for learning, reflection and dialogue, the contribution to the eradication of growing xenophobia in the context of the city, and in this way build a culture of peace, and in turn make effective articles 44, 13, and 67 of the Political Constitution of Colombia

In Colombia, children's rights prevail over the rights of others, as promulgated in article 44 of the Constitution, as well as the jurisprudential ratification developed by the Honorable Constitutional Court in various judgments, such as T-743 of 2013, T-105 of 2017 and T-434 of 2018.

Intervention in childhood is very important, since it is the stage of life in which the behavior we will have as adults in society is conceived. For this reason, it was considered pertinent to carry out pedagogical recreational activities in the primary grades of the educational institutions of the city with the greatest affluence of Venezuelan migrant children, since it is also one of the sectors most prone to suffer violations of their human rights.

One of our guidelines as participants in the research project was to promote the appropriation of their human rights, mainly equality and the rejection of discrimination, in primary schools in Cúcuta, taking into account that Venezuelan migrant children are in a vulnerable situation due to their condition, in addition to the consequences of migration, such as socioeconomic difficulties and placement in a lower 
academic year than the one they were attending in Venezuela, finding themselves in the classroom with classmates of a different age than theirs.

In order to identify the receiving educational institutions, we requested information from the Secretary of Education of the Municipality on the schools with the highest influx of Venezuelan students, obtaining a prompt response, specifying the number of Venezuelan students enrolled by each public school, as shown in the table below.

\begin{tabular}{|c|c|c|c|c|c|c|}
\hline INSTITUCIÓN EDUCATIVA & CE & NES & PEP & TMF & VISA & TOTAL \\
\hline COL PABLO CORREALEON & 8 & 645 & 6 & 28 & & 687 \\
\hline COL BAS CAMILO DAZA & 6 & 468 & 4 & 5 & 1 & 484 \\
\hline IE. JUAN PABLOI & 5 & 325 & 17 & 16 & & 363 \\
\hline COL EUSTORGIO COLMENARES BAPTISTA & & 254 & 63 & 42 & & 359 \\
\hline COL MARIANO OSPINA ROORIGUEZ & 14 & 258 & 35 & 45 & & 352 \\
\hline COL ANTONIO NARENO & & 331 & 10 & 1 & & 342 \\
\hline COL CLAUDIA MARLA PRADA AYALA & 1 & 301 & 1 & & & 303 \\
\hline COL CARLOS PEREZ ESCALANTE & 5 & 283 & 6 & 6 & 2 & 302 \\
\hline COL MPAL SIMON BOLNAR & 3 & 186 & S5 & so & & 294 \\
\hline COL SAN JOSE DE CUCUTA & 12 & 282 & & & & 294 \\
\hline
\end{tabular}

Table I. Institutions with Venezuelan Students

Bearing in mind that play is a naturally happy activity that integrally develops man's personality and in particular his creative capacity. As a pedagogical activity it has a marked didactic character and fulfils the intellectual, practical, communicative and evaluative elements in a playful way (Ocaña, 2009).

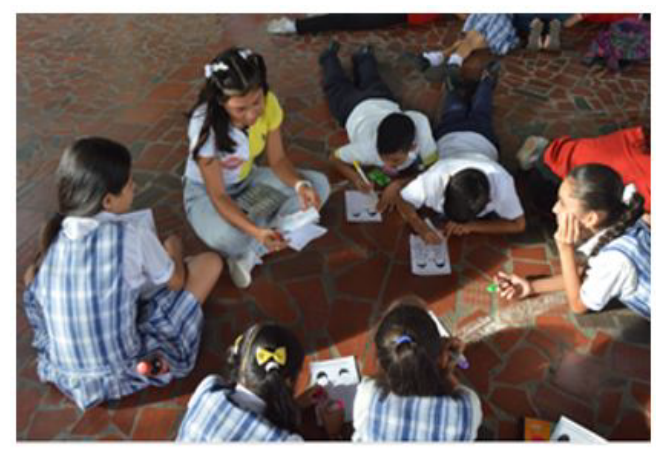

Figure 1. Ludic activity
The activities were proposed in order to raise awareness of the reasons for migration, and through pedagogy and play, to build a multicultural society in which the defence of human rights and equality prevail.

As shown in Table I, the institution with the largest number of Venezuelan students is the Pablo Correa León School. When we approached the educational entity, we received a great reception from the rector, Julio César Delgado Hernández, who allowed us to carry out the proposed activity in the primary school.

In the activities carried out with the primary students there was a cordial and collaborative atmosphere on the part of the teachers, and enthusiasm on the part of the children.

The school's court was set up as a space for the activity, where the instructions were given and the educational play activities were developed.

First we made the presentations to the students, in order to make known the objective of the day, and we had the authorization of the school and the informed consent of the parents.

During the day we performed dramatizations and games about cases of xenophobia in the classroom, and through questions and interaction with the children we identified the actions and responses that promoted rights or that violated them, identifying themselves as equal human beings, regardless of gender, race, age, height, etc.

Concepts were socialised and explained through play and dynamics what human rights are; children had certain concepts about human rights and their importance, and it was also possible to identify that they had normalised discriminatory attitudes and practices that they saw in their environment. So, by talking and presenting situations that should not be repeated in the classroom, they began to associate 
the idea that they are equal in rights, have the same conditions, and how their actions in certain cases need to be improved.

We drew their figures on paper, which we then used as a mural where the values they committed to promote to live in equality and eliminate discrimination were expressed.

We remain committed to continuing these activities in the other public schools listed in Table I in the city of San José de Cúcuta.

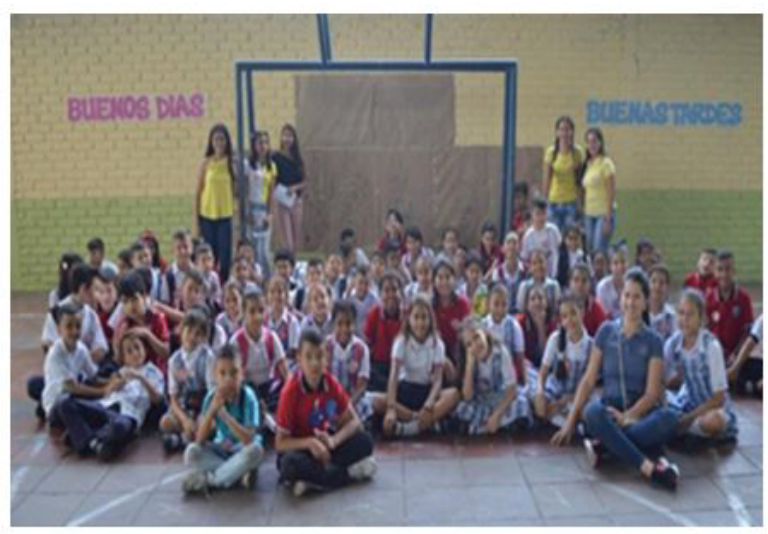

Figure 2. End of the activity.

\section{Conclusions}

- Children and adolescents who are migrants have their rights protected at the international level, through instruments such as the Convention on the Rights of the Child, among others, and at the national level through the guarantees offered by the Colombian Constitution and the Code for Children and Adolescents.

- Equality and the right to education must be promoted through policies, plans, programmes and actions by States for the protection of the best interests of children and adolescents, regardless of their status as nationals or foreigners.

- The school as a transformative space plays a very important role in society for the formation of children who are subjects of rights and who promote a culture of peace.

- The problem of migration has had an impact on the city of San José de Cúcuta, as the recipient of the Venezuelan population, and measures must be taken at the national, departmental and municipal levels.

- The city's educational institutions find it necessary to promote equality and non-discrimination in the face of the migration situation.

- The University, within its social responsibility, through its research seedbeds, intervenes and acts in favour of improving and contributing to the solution of the region's problems.

- Play and games are tools for the discovery and learning of children, allowing the adoption of concepts through activities that bring them joy.

- Childhood is an ideal stage for the construction of citizenship and the promotion of human rights, and play and pedagogical activities are a great tool for the development of children's capacities.

\section{Acknowledgements}

It has been very satisfying to be able to develop this project, as well as the opportunity to continue replicating its results in other educational institutions, which is why we thank the Municipal Education Secretariat for its collaboration in identifying and providing information, as well as the directors of the educational institution Colegio Pablo Correa León, at its María Auxiliadora site, for allowing us to carry out the activities and being so willing to work together for the formation of their students.

\section{References}

Declaración Universal de Derechos Humanos (1948) Naciones Unidas. Recuperado de https:// www.ohchr.org/EN/UDHR/Documents/UDHR_ Translations/spn.pdf 
Huizinga, Johanes (1987). Homo Ludens. México:

Fondo de Cultura Económica.

Asamblea General Naciones Unidas (1989). Convención sobre los Derechos del Niño. Recuperado de https://www.ohchr.org/sp/ professionalinterest/pages/crc.aspx

Asamblea General Naciones Unidas (1990). Convención sobre la protección de los derechos de todos los trabajadores migratorios y de sus familiares. Recuperado de https://www.ohchr. org/sp/professionalinterest/pages/cmw.aspx

Constitución Política de Colombia (1991). Recuperado de http://www.secretariasenado.gov. co/senado/basedoc/constitucion_politica_1991. html

Ferrari, C. (1994). ¿Qué es el juego? Alrededor del fútbol. Revista Universidad de Antioquia LXIII. 236: 47-49.

Código de la Infancia y la Adolescencia (2006). Ley 1098 de 2006. Recuperado de https://www.icbf. gov.co/cargues/avance/docs/ley_1098_2006.htm

Ruiz García, Aida (2002) Migración oaxauqueña, una aproximación a la realidad. Oaxaca: Coordinación Estatal de Atención al migrante Oaxaqueño. P19.

Duarte D., Jakeline. (2003). Ambientes de Aprendizaje: Una Aproximación Conceptual. Estudios pedagógicos (Valdivia), (29), 97113. $\quad$ https://dx.doi.org/10.4067/S071807052003000100007

Corte Interamericana de Derechos Humanos (2005). La Corte Interamericana de Derechos Humanos un cuarto de siglo: 1979 - 2004.

Suárez-Orozco, C. y M. Suárez-Orozco (2003). La Infancia de la Inmigración. Morata, Madrid.

Feixa, C. (dir.). (2006). Jóvenes "Latinos" en Barcelona. Espacio Público y Cultura Urbana. Anthropos, Barcelona.

Sandell, R., Sorroza Blanco, A., y Olivié Aldasoro, L. (2007). Inmigración: ¿un desafío con oportunidades? Boletín Elcano.

Alegre, M. (2007). Geografies Adolescents a Secundaria. Posicionaments Culturals i Relacionals deis i les Joves d'Origen Immigrant . Observatori Catala de la Joventut, Barcelona.
Liwski, Norberto I. (2008) Instituto Interamericano del Niño, la Niña y Adolescentes, Comisión especial de asuntos migratorios. Recuperado dehttps://www. fundacionhenrydunant. org/images/stories/biblioteca/ddhhjuventud/Informe $\% 20$ al $\% 20$ Consejo $\% 20$ Permanente-OEA_Migraciones $\% 20 \mathrm{de} \% 20$ $\mathrm{Ni} \% \mathrm{C} 3 \% \mathrm{~B} 1$ os $\% 20 \mathrm{Ni} \% \mathrm{C} 3 \% \mathrm{~B} 1$ as $\% 20 \mathrm{y} \% 20$ Adolescentes \%20bajo\%20el\%20Enfoque $\% 20$ de\%20Derechos.pdf

De Flores, R. Á. (2009). Refugiados entre fronteras: La nueva realidad migratoria colombovenezolana. Observatorio Laboral Revista Venezolana

Ortiz, Ocaña (2009). Jugando Tambien se aprende. Madrid: Didáctica.

Universidad Francisco de Paula Santander (2011). Resolución 121 del 24 de mayo de 2011 del Consejo Académico.

Echeverry Hernández, A. A. (2012). Análisis de la migración venezolana a Colombia durante el gobierno de Hugo Chávez (1999-2011). Identificación de capital social y compensación económica. Revista Análisis Internacional, 1(4), 33-52.

Red Migrante; Migración Colombia (2013). RED MIGRANTE: "Garantías y servicios para el migrante en Colombia". Obtenido de http:// migracioncolombia.gov.co/phocadownload/ cartilla_red_migrante.pdf

Ortega Velázquez, E. (2015). Los niños migrantes irregulares y sus derechos humanos en la práctica europea y americana: entre el control y la protección. Boletín Mexicano de Derecho Comparado, 1(142).https://doi.org/10.22201/ iij.24484873e.2015.142.4919

Posso, P., Sepúlveda, M., Navarro, N. y Laguna, C.E. (2015). La lúdica como estrategia pedagógica para fortalecer la convivencia escolar. Lúdica Pedagógica, (21), 163-174.

Gamboa-Suárez, A. A. (2016). Docencia, investigación y gestión: Reflexiones sobre su papel en la calidad de la educación superior. Revista Perspectivas, 1(1), 81-90. https://doi. 
org/10.22463/25909215.973

Ministerio de relaciones exteriores (2017). Radiografía de Venezolanos en Colombia. Recuperado de https://www.migracioncolombia. gov.co/documentos/comunicaciones/infografias/ radiografia_web_2017.pdf

Sarmiento. K. (2017). Radiografía de Venezolanos en Colombia. Migración. Ministerio de relaciones exteriores. Recuperado de https:// www.migracioncolombia.gov.co/documentos/ comunicaciones/infografias/radiografia web_2017.pdf

Unidad Nacional para la Gestión del Riesgo de Desastres Colombia. (2018). Ruta de atención para migrantes venezolanos en Colombia. Obtenido de http://portal.gestiondelriesgo.gov. co/RAMV/SiteAssets/SitePages/

Ministerio de Relaciones Exteriores (2018) Presentación Migración Venezolana en Colombia.

Banco Internacional de Reconstrucción y Fomento/ Banco Mundial, \& State and peacebuilding fund. (2018). Migración desde Venezuela a Colombia: impactos y estrategia de respuesta en el corto y mediano plazo. Recuperado de https://r4v.info/ es/documents/download/66643

Gerencia de Frontera (2018) Presentación para el Banco Mundial Somos Frontera: Seguridad, Control, Solidaridad.

Departamento Nacional de Planeación (2018). Documento CONPES 3950, estrategia para la atención de la migración desde Venezuela. Recuperado de https:/colaboracion.dnp.gov.co/ CDT/Conpes/Econ\%C3\%B3micos/3950.pdf

Fundación Panamericana para el Desarrollo, y la Oficina de Población, Refugiados, y Migración del Departamento de Estado de los Estados Unidos, Universidad del Rosario, Organización de los Estados Americanos, \& FUPAD Colombia (2019). EL ACCESO A LOS DERECHOS DE LOS MIGRANTES EN COLOMBIA. Recuperado de https://www.oas.org/es/sadye/documentos/ FUPAD_CartillaDerechos.pdf

García Arias, M. F., \& Restrepo Pineda, J. E.
(2019). Aproximación al proceso migratorio venezolano en el siglo XXI. Hallazgos. https:// doi.org/10.15332/2422409x.5000

Pinto, L. A., Baracaldo Amaya, P., \& Aliaga Sáez, F. (2019). La integración de los venezolanos en Colombia en los ámbitos de la salud y la educación. Espacio Abierto, 28(1), 205-210. Recuperado de Dialnet-LaIntegracionDeLosVe nezolanosEnColombiaEnLosAmbito-6942244. pdf 